\author{
PAWEŁ WIĄZEK \\ ORCID: 0000-0002-9153-4539 \\ Uniwersytet Wrocławski \\ pawel.wiazek@uwr.edu.pl
}

\title{
Posłowie wobec problemu reformy prawa sądowego w pierwszym roku obrad Sejmu Wielkiego w świetle diariuszy sejmowych Jana Pawła Łuszczewskiego i Antoniego Siarczyńskiego
}

Nowy codex praw cywilnych i kryminalnych przez wyznaczone przez sejm osoby spisać rozkazujemy ${ }^{1}$.

\section{Uwagi wstępne}

Dyspozycja Ustawy Rządowej nie została zrealizowana do końca istnienia Rzeczpospolitej Obojga Narodów. Odpowiedź na fundamentalne w tym kontekście pytanie o przyczynę takiego stanu rzeczy pozostaje kwestią otwartą, pomimo trwającej od dziesięcioleci i wciąż toczącej się dyskusji z udziałem setek badaczy dziejów państwa i prawa. Mam na myśli nie tyle całe szerokie spektrum poglądów na przyczyny upadku Rzeczypospolitej (w ogólności), ile problematykę zawężoną do braku reform $\mathrm{w}$ dziedzinie prawa sądowego. Wbrew pozorom nie tak wiele to zmienia, bowiem nawet tak ograniczona, wydawałoby się, problematyka badawcza obfituje w mnogość wątków oraz rozbieżność uwag, ocen i wniosków. I absolutnie nic w tym ani nadzwyczajnego, ani tym bardziej — zdrożnego. Polemika,

1 Ustawa Rządowa z dnia 3 maja 1791 roku, rozdz. VIII. Władza sądownicza, in fine, Volumina Legum (dalej: VL), t. 9, Kraków 1889, s. 224. 
kontrowersje i żarliwe częstokroć spory stanowią przecież codzienność, clou świata badaczy. Brak jednoznacznej aprobowanej przez wszystkich „,prawdy absolutnej" w niczym nie podważa dorobku badań prowadzonych przez inicjatorów eksploracji; analogicznie — w żaden sposób nie deprecjonuje sensu i wartości badań wciąż prowadzonych w obrębie podejmowanej już tematyki.

Kluczowe z punktu widzenia podjętej problematyki badawczej pojęcie: „prawo sądowe", nie budzi w naukach prawnych poważniejszych kontrowersji. Jego istota postrzegana jest zazwyczaj z perspektywy znaczenia określonych działów prawa w działalności orzeczniczej sądów. W konsekwencji tradycyjnie obejmuje ono materię prawa karnego (dawniej kryminalnego), cywilnego (określanego niegdyś częściej mianem prywatnego) — tak materialnego, jak i formalnego, a także postanowienia o ustroju sądów.

Podstawę źródłową niniejszej publikacji stanowią dwie zdygitalizowane edycje diariuszy Sejmu Wielkiego (głównie autorstwa sekretarzy królewskich²: Jana Pawła Łuszczewskiego ${ }^{3}$ oraz Antoniego Siarczyńskiego ${ }^{4}$ ) z roku 2005, wydane staraniem Agnieszki Królczyk i Rafała T. Prinke'go, sygnowane: PAN Biblioteka Kórnicka 5 . Relacjonują one wystąpienia poselskie na forum sejmowym

2 Stanowili oni osobną kategorię pracowników królewskiego gabinetu. Do ich obowiązków należało opracowywanie korespondencji pod dyktando króla, konsyliarzy lub szefa gabinetu bądź na podstawie sporządzonej przez nich minuty. Sekretarze zajmowali się także szyfrowaniem i deszyfrowaniem pism, przechowywaniem kopii korespondencji. Prowadzili również „sekreterę” sejmową, traktowaną jako splendor, wyróżnienie oraz nagrodę pieniężną; Z. Chyra-Rolicz, Gabinet Stanisława Augusta, [w:] Dzieje biurokracji na ziemiach polskich, t. 1, red. A. Górak, I. Łuć, D. Magier, Lublin-Siedlce 2008, s. 95.

3 Jan Paweł Łuszczewski (1764-1812), pieczętujący się herbem Pierzchała (zob. E. Michałowska-Walkiewicz, Jan Pawet Łuszczewski - polski polityk Księstwa Warszawskiego, https:// poland.us/strona, 13,30673,0,jan-pawel-luszczewski-polski-polityk-ksiestwa-warszawskiego.html (dostęp: 4.02.2021)), a następnie Korczak (A. Boniecki, A. Reiski, Herbarz polski, t. 16, Warszawa 1913, s. 152; S. Uruski, Rodzina. Herbarz szlachty polskiej, t. 10, Warszawa 1913, s. 60-63), był jednym z najaktywniejszych polityków Sejmu Wielkiego. Jako członek Stronnictwa Patriotycznego był gorącym orędownikiem Ustawy Rządowej, którą z wrodzoną sobie pasją popierał między innymi w mowach wygłaszanych w senacie. Był jednym z 83 sygnatariuszy Asekuracyi zobowiązującej do popierania w sejmie projektu Ustawy Rządowej z dnia 2 maja 1791 roku. Od połowy lat osiemdziesiątych XVIII stulecia aż do momentu abdykacji Stanisława Augusta (w latach 1785-1795) był sekretarzem Gabinetu Jego Królewskiej Mości. W dobie Sejmu Czteroletniego był królewskim sekretarzem sejmowym i sekretarzem skonfederowanych prowincji koronnych (M. Rymszyna, $G a$ binet Stanistawa Augusta Poniatowskiego, Warszawa 1962, s. 185). Po upadku Rzeczypospolitej w Księstwie Warszawskim pełnił (w latach 1807-1812) funkcję ministra spraw wewnętrznych.

${ }^{4}$ Sekretarz przyboczny Stanisława Augusta, dwukrotnie pełniący funkcję sekretarza sejmowego. Trwałą pozycję w historiografii zapewniło mu dzieło zatytułowane Dzień Trzeci Maia roku 1791, wydane najpewniej jeszcze w roku uchwalenia Ustawy Rządowej nakładem i drukiem Michała Grölla jako Księga JKM; o osobie autora diariusza zob. także A. Grześkowiak-Krwawicz, Siarczyński Antoni (1757-1842), [w:] Polski Słownik Biograficzny, t. 36. Schroeder Franciszek Siemiatycki Chaim, Warszawa-Kraków 1995-1996, s. 446-447.

5 Diariusz Sejmu Czteroletniego (sesje 1/06.10.1788-71/06.03.1789), z drukowanego wydania Jana Pawła Łuszczewskiego, Dyaryusz seymu ordynaryinego pod zwiazkiem Konfederacyi 
w pierwszym, niewiele ponad rocznym okresie jego obrad, to jest od 6 października 1788 po przełom listopada i grudnia roku 1789.

\section{Znaczenie i pozycja diariuszy sejmowych $\mathrm{w}$ instrumentarium historiografii}

W literaturze przedmiotu panuje zgodny pogląd na temat wyjątkowego znaczenia diariuszy jako źródeł poznania dawnego prawa. Stanowią one bezcenny materiał do badań nad staropolskim parlamentaryzmem, których niezwykłe walory dawno już doceniono. Ich wnikliwa lektura przybliża obraz funkcjonowania dawnej Rzeczpospolitej. Spisywane na sejmach są wspaniałym źródłem poznania przebiegu obrad sejmowych. Sporządzano je zarówno w środowisku poselskim, jak i senackim; rzadko jednak można wskazać konkretną osobę jako autora diariusza, najczęściej są to tylko bardziej lub mniej prawdopodobne domysły. Czasem sporządzane były przez samych posłów, innym razem przez przedstawicieli publiczności, na przykład dworzan magnackich. Mimo ich różnorodności, a może dzięki niej, tworzą nieocenioną możliwość poznania sposobu głosowania, stanowiska króla, senatu i samych posłów, układów, ugrupowań politycznych, koncepcji prawnych, postaw działaczy, elity politycznej oraz kultury i obyczajowości sejmowej. Opisy obrad dostarczają niezliczonej ilości przykładów zachowań posłów i senatorów, którzy niejednokrotnie wyrażali swe poglądy i emocje w sposób bardzo gwałtowny i pełen ekspresji. Dzięki tym zapiskom można także prześledzić, jak szlachecka ideologia i ceremoniał sprawdzały się w praktyce ${ }^{6}$.

Przez pierwsze półtora wieku istnienia sejmu walnego diariusze powstawały wyłącznie z inicjatywy prywatnej: magnatów, ale także miast pruskich (zwłaszcza Gdańska). Dopiero za panowania Jana Kazimierza zaczęto sporządzać diariusz „oficjalny”, przygotowywany przez kancelarię koronną ${ }^{7}$. W wieku XVIII

Generalney oboyga narodow w Warszawie rozpoczętego roku 1788, Warszawa Druk. Nadworna J.K.Mci i [...] Kommis. Ed. Narod. 1790, t. 1, cz. 1-2; t. 2, cz. 1-2, https://www.wbc.poznan.pl/dlibra/show-content/publication/edition/32987?id=32987\&from=FBC (dalej: D1) (dostęp: 5.02.2021); Diariusz Sejmu Czteroletniego (sesje: 98/4.05.1789-198/30.11.1789 i 327/12.10.1790), z rękopisu przechowywanego w AGAD (w zbiorze Archiwum Sejmu Czteroletniego, rozproszony w różnych tomach) autorstwa Jana Pawła Łuszczewskiego, Antoniego Siarczyńskiego i in., https://www.wbc. poznan.pl/dlibra/publication/20159/edition/32995/content (dalej: D2) (dostęp: 5.02.2021).

6 M. Pieńkowski (rec.), Diariusze sejmu koronacyjnego Zygmunta III Wazy 1587/1588 roku, Kraków 2016, „Klio. Czasopismo Poświęcone Dziejom Polski i Powszechnym” 40, 2017, nr 1, s. 155-156; A. Kalinowska, Diariusze sejmowe, „Silva Rerum”, https://www.wilanow-palac.pl/diariusze_sejmowe.html (dostęp: 4.02.2021).

${ }^{7}$ Przekazy o nim pochodzą z okresu panowania Jana Kazimierza, gdy posłowie uskarżali się na obecność sekretarzy królewskich spisujących obrady. Z czasem zaakceptowano tę praktykę, tak iż w 1669 roku protestowano jedynie przeciwko obecności w izbie prywatnych skrybów. Oficjalny 
ten właśnie diariusz stał się podstawą dla innych; jednak do końca istnienia Rzeczypospolitej szlacheckiej nie był źródłem w pełni oficjalnym, to znaczy — jego powstawanie nie zostało prawnie uregulowane przez sejm. Warto przy tym pamiętać, że w praktyce sejmowania wiele było form zwyczajowych, nieopartych na formalnej regulacji prawnej. Przez cały wiek XVIII powstawały nadal diariusze niezależne od oficjalnego ${ }^{8}$.

\section{Reforma prawa sądowego w wotach poselskich w świetle diariuszy}

Obrady Sejmu Wielkiego zgodnie z zapowiedzią uniwersału przedsejmowego rozpoczęły się formalnie, ,podług Prawa, w pierwszy Poniedziałek po S. Michale, to iest; dnia Szostego Miesiąca Października [1788]"9. Pierwsze trzy sesje (6-8 października 1788) miały charakter organizacyjno-porządkowy, związany głównie z decyzjami o obradowaniu pod węzłem konfederacji i obiorem marszałków. Merytoryczną debatę rozpoczęto dopiero wraz z początkiem czwartej sesji, to jest 13 października. Wówczas bowiem podkanclerzy koronny Maciej Grzegorz Garnysz ${ }^{10}$ przedstawił zgromadzonym posłom cztery Propozycje od tronu. Pierwsza z nich postulowała konieczność oszacowania stanu finansów publicznych i wskazania źródeł finansowania najpilniejszych potrzeb państwa; druga - podjęcia, w oparciu o wyniki tych ustaleń, decyzji o aukcji wojska. Dopiero trzecia (jako jedyna) zwracała uwagę na interesujący nas problem reformy prawa sądowego. Referujący stanowisko króla względem priorytetowych spraw państwa stwierdzał w niej bowiem: „Po tych poprzedzaiących Obiektach, nastąpić będą mogły poprawy Sądowości, których się potrzeba naynagleysza pokaże, które to, równie, iako y inne materye poźnieyszemu Seymowania zaradzeniu zostawuie Jego Królewska Mość" ${ }^{11}$. Wypada więc zgodzić się z reprezentowanym już w literaturze stanowiskiem uznającym, że propozycje od tronu przedstawione na początku obrad sejmowych wskazywały, iż panujący świadomy był pilnej potrzeby reformy prawa sądowego do tego stopnia, że publicznie dał wyraz przekonaniu o konieczności podjęcia dyskusji sejmowej poświęconej

diariusz spisywali pisarze sejmowi, którzy otrzymywali za tę pracę dodatkowe wynagrodzenie. Ten najpełniejszy diariusz, który należałoby określać mianem oficjalnego, był najbardziej zbliżony do współczesnych stenogramów z posiedzeń sejmu; J. Nowicki, Diariusze sejmowe z XVIII wieku, „Mówią Wieki” 10, 1998, s. 15.

8 Ibidem, s. 14.

${ }^{9}$ D1, wstęp.

${ }^{10}$ Funkcję tę piastował on od roku 1786; od 1781 był także biskupem płockim.

11 D1, Sesja $4-13.10 .1788$. 
temu zagadnieniu ${ }^{12}$. Nie przeceniałbym jednak jej wagi w kontekście dalszego przebiegu debaty poselskiej; przynajmniej w pierwszych jej miesiącach, choć $\mathrm{w}$ istocie — w całej pierwszej kadencji Sejmu.

Na plan pierwszy zdecydowanie wysunęły się inne kwestie. Szczególnie chętnie i częstokroć namiętnie podejmowano problematykę geopolityczną, ścierając się w opiniach na temat kierunków polityki zagranicznej państwa, jej ocen i prognoz rozwojowych. Doskonale spełniała się ona jako wyjątkowo dogodna dla popisów oratorskich polemiczna przestrzeń prowadzonego dyskursu. Troska o dobro umiłowanej ojczyzny grzmiała w każdym niemal wygłaszanym zdaniu, przy czym świadomość rzeczywistych intencji wielu posłów nie była tajemnicą dla uczestników prowadzonych sporów. Świadczy o tym choćby fakt, że przedstawiona przez posła dworu berlińskiego Ludwiga Heinricha Buchholtza Deklaracja do Stanów Skonfederowanych ustosunkowująca się do zgłoszonej przez reprezentującego dwór petersburski ambasadora rosyjskiego grafa Ottona Magnusa von Stackelberga propozycji ścisłego aliansu polsko-rosyjskiego poprzedziła nawet przedstawienie Propozycji od tronu przez podkanclerzego koronnego.

Pierwsze merytoryczne sesje parlamentu zdecydowanie zdominowała aukcja wojska. Choć punktem wyjścia toczonej debaty uczyniono jego liczebność, to jednak wkrótce pojawiły się na forum obrad plenarnych liczne kwestie związane z jego organizacją, strukturą czy kadrą dowódczą. Atmosfera dyskursu gęstniała, a temperatura wzrastała, gdy zaczęły pojawiać się kwestie dotyczące komisji wojskowych, pozycji hetmanów, a wkrótce także kompetencji Rady Nieustającej. Na kanwie szeroko pojętej i podjętej tematyki reformy wojskowości pojawiły się także wystąpienia, które do pewnego stopnia można łączyć z problematyką prawno-sądową, a mianowicie - dotyczące odpowiedzialności karnej osób wojskowych dopuszczających się pogwałcenia prawa w toku realizacji swych uprawnień i wykonywania obowiązków. Jeśli jednak problematyka ta pojawiała się w głosach poselskich, to próby jej podejmowania niewiele miały wspólnego z dojrzałą koncepcją systematycznej reformy, choćby tylko w określonych segmentach wyodrębnionej problematyki. Wystąpienia miały charakter incydentalny i okazjonalny. Pojawiały się w kontekście zarzutów formułowanych ad hoc wobec konkretnych osób. Reprezentatywnym tego przykładem było podjęcie sprawy odpowiedzialności prawnej marszałka Sejmu Rozbiorowego z lat 1773-1775 Adama Ponińskiego ${ }^{13}$. Została ona poruszona na początku czerwca 1789 roku, a do głównych inicjatorów i zwolenników pociągnięcia księcia Ponińskiego do odpowiedzialności należeli Stanisław Kublicki (inicjator pierwszego imiennego zarzutu), Wojciech Suchodolski (w którego wystąpieniach pojawiła się obszerna lista zarzutów kryminalnych), jak również posłowie Tadeusz Morski oraz Józef

12 W. Szafrański, Kodeks Stanisława Augusta, Poznań 2007, s. 44.

13 Szerzej na ten temat zob. R. Chojecki, Stanisław August a proces Adama Ponińskiego, „Przegląd Historyczny” 63, 1972, nr 1, s. 31-48. 
Weyssenhoff. Inicjatywę storpedował jednak wówczas sam monarcha, uzasadniając swój sprzeciw koniecznością obrony zasady neminem captivabimus. Stanowisko panującego znalazło poparcie wielu posłów, przy czym szczególnie warto w interesującym nas kontekście zwrócić uwagę na reprezentatywny dla konserwatywnej świadomości i mentalności prawnej ówczesnej szlachty głos posła trockiego Michała Antoniego Zaleskiego, który swoje zachowawcze stanowisko uzasadniał, perorując: „W materyi dziś y ongi toczącey się troskliwość naszę dzielić mamy na prawo, y na występek [...]. Występek wart Kary, ale też y prawo swego zachowania. Nie mówię za występkiem, ale mówię, za Prawem Neminem captivabimus nisi jure victum. Lękam się, aby z postąpienia Prawa na winny toż Prawo potym na niewinnych gwałcone niebyło" ${ }^{14}$.

Podobnie incydentalny charakter miało podjęcie nieco wcześniej, bo w maju 1789 roku, problematyki karnoprawnej wskutek alarmujących informacji o krwawych chłopskich buntach, jakie docierały ze wschodnich prowincji Rzeczypospo$\operatorname{litej}^{15}$. Z zagajeniem w tej sprawie wystąpił marszałek Stanisław Małachowski, zgłaszając „Proiekt wyznaczenia tymczasowych Sędziow do wysłuchania Indagacyi z obwinionych o Bunty Inkarceratów"16. W atmosferze zagrożenia pojawiły się podczas obrad sejmowych głosy postulujące zaostrzenie kar za mężobójstwo, uproszczenie procedur zmierzających do pociągnięcia sprawców do odpowiedzialności karnej z tytułu popełnionych zbrodni. Wśród podejmujących problem posłów wypada wymienić przede wszystkim Symeona Szydłowskiego, Józefa Korwina Kossakowskiego, Wojciecha Augustyna Świętosławskiego czy wspomnianych już Wojciecha Suchodolskiego oraz Antoniego Zaleskiego ${ }^{17}$. Żadnych trwałych skutków w postaci zmian w prawie wystąpienia te nie przyniosły.

Nie inaczej rzecz miała się z zainteresowaniem posłów problematyką reformy prawa prywatnego. Trudno się temu dziwić, biorąc pod uwagę ugruntowane słusznie przekonanie, że dziedzina ta jest bardziej konserwatywna i w konsekwencji mniej podatna na nagłe głębokie zmiany. Wykazując daleko idący optymizm, można było teoretycznie zakładać, że w związku z koniecznością pomnożenia dochodów skarbu publicznego pojawi się wśród deputowanych głębsza perspektywa spojrzenia skutkująca ograniczonymi choćby inicjatywami w zakresie

14 D2, Sesja $113-4.06 .1789$, Sesja $114-5.06 .1789$, i Sesja $115-8.06 .1789$.

$15 \mathrm{Na}$ ten temat zob. np. M. Trąbski, Zagrożenie buntem chtopskim w poludniowowschodnich województwach Rzeczypospolitej Obojga Narodów w latach 1788-1789, „Orientalia Christiana Cracoviensia” 2015, nr 7, s. 91-116; W.A. Serczyk, Hajdamacy, Kraków 1978, s. 398; T. Srogosz, Zagrożenie bezpieczeństwa na kresach poludniowowschodnich Rzeczypospolitej w końcu lat osiemdziesiątych XVIII wieku w świetle korespondencji wojewody kijowskiego Józefa Gabriela Stempkowskiego, „Prace Naukowe Akademii im. Jana Długosza w Częstochowie. Zeszyty Historyczne” 13, 2014, s. 89.

16 D2, Sesja $106-19.05 .1789$.

17 D2, Sesja 106 - 19.05.1789, Sesja 111 - 29.05.1789, Sesja 112 - 2.06.1789, Sesja 113 -4.06 .1789 . 
emancypującego się prawa handlowego lub przynajmniej prawa obligacyjnego. Wnikliwa analiza eksplorowanych źródeł pozbawia jednak złudzeń. Nic takiego nie miało miejsca, wyjąwszy może zgłoszoną nieśmiało obawę posła Suchodolskiego o wykorzystanie w celach fiskalnych instytucji wydefkaufu ze szkodą dla interesów finansowych obywateli ${ }^{18}$.

W literaturze niejednokrotnie zwracano już uwagę na szczególny konserwatyzm praktyki legislacyjnej I Rzeczpospolitej, wyjątkowo silnie zakorzenione przekonanie o stabilności prawa jako istotne spoiwo wielonarodowego państwa, powszechność postawy obywateli dawnych epok przekonanych, że im starsze prawo, tym większe jego poważanie, tym większy autorytet. Tradycjonalizm ten, kultywowany przez wieki, w istocie po kres niepodległego bytu państwowego u schyłku XVIII stulecia ${ }^{19}$. Opinię tę zdają się potwierdzać także wyniki najnowszych eksploracji innych badaczy, prowadzonych już w obecnym stuleciu ${ }^{20}$.

Nie dziwi zatem, że powołana we wrześniu 1789 roku deputacja do poprawy formy rządu ograniczyła się wyłącznie do reformy ustrojowej ${ }^{21}$, zaś w żadnej z trzech opracowanych przez nią projektów Zasad do poprawy Formy Rządu nie było nawet wzmianki na temat powołania komisji dotyczącej reformy prawa sądowego. Nie dziwi w konsekwencji i to, że za pierwszy krok na drodze do realizacji myśli kodyfikacyjnej na forum sejmowym uznawana jest wygłoszona dopiero na sesji 213 w dniu 28 grudnia 1789 roku mowa posła bracławskiego Seweryna Potockiego, w której perorował o niesprawiedliwości i opieszałości w działaniu sądownictwa w Rzeczpospolitej ${ }^{22}$.

\section{Uwagi końcowe}

W literaturze przedmiotu kultywowany jest pogląd uznający, że „w epoce stanisławowskiej wielokrotnie podejmowano próby reformy prawa [sądowego - P.W.], które stanowić miały element ogólnej przebudowy stosunków ustrojowych i społeczno-gospodarczych"23. Trudno polemizować z podobną tezą,

18 D2, Sesja 106. Na temat wyderkaufu zob. P. Wiązek, Wyderkauf jako forma obejścia przepisów o lichwie w prawie przedrozbiorowej Polski, [w:] Regulacje prawne gospodarki w rozwoju historycznym, red. A. Szymańska, Wrocław 2017, s. 109-118.

19 P. Wiązek, O powolaniu naszych czasów do ustawodawstwa: konsolidacja, unifikacja, korektura czy kodyfikacja? Polemiki wokót ponderabiliów w sporze o reforme prawa sądowego u schytku osiemnastowiecznej Rzeczpospolitej, „Prawo” 314, 2012, s. 64.

20 Por. W. Szczygielski, Z badań nad początkami obrad Sejmu Wielkiego, „Przegląd Nauk Historycznych" 7, 2008, nr 1, s. 21-84.

${ }^{21}$ D2, Sesja $152-7.09 .1789$.

22 Por. W. Szafrański, op. cit., s. 44.

23 Ibidem, s. 314. 
przyjmując analogiczną, to jest całościową perspektywę oglądu rzeczy, kreowaną przez prymat trzydziestoletniej „epoki”. Ten relatywnie długi okres rządów ostatniego monarchy przedrozbiorowej Polski to jednak okres niezwykle dynamiczny, obfitujący w mnogość wydarzeń, które w nagły niejednokrotnie sposób zmieniały rzeczywistość państwa polsko-litewskiego; zwłaszcza jego sytuację geopolityczną, a w konsekwencji - charakter, priorytety, intensywność i kierunki decyzji oraz działań zarówno ścisłej elity przywódców, jak i szerokich rzesz „panów-braci”, czyli ówczesnego narodu politycznego. Przyjmując podobną krótkookresową optykę spojrzenia na podjęty problem badawczy efekty eksploracji skłaniać mogą do mniej jednoznacznych i korzystnych ocen.

O ile działalność reformatorską w latach 1764-1768 w kontekście realnie dokonanych zmian w prawie sądowym eufemistycznie określiłbym mianem dyskretnej ${ }^{24}$, to już „wielokrotnie podejmowane próby reformy” wobec losów tak zwanego kodeksu Zamoyskiego zdecydowanie nie zasługują, moim zdaniem, nawet na tak oględną, względnie korzystną ocenę. Po wielu cierpkich uwagach wobec kodyfikatorów i efektu ich wysiłków, po żenującej często argumentacji prezentowanej na forum sejmowych obrad plenarnych, łączony z osobą kanclerza i jednoznacznie popierany przez panującego projekt Zbioru praw sądowych zakończył swój niedoszły żywot spektakularną klęską. Odrzucając projekt ${ }^{25}$, nie omieszkali posłowie expressis verbis uzupełnić in fine stosowną uchwałę żądaniem, by „na żadnym Seymie [...] nie był wskrzeszany" 26 .

Sejmy walne, które odbywały się w latach 1778-1786, miały nikłe znaczenie z punktu widzenia liczby uchwalanych ustaw i ich wagi ${ }^{27}$. Po odrzuceniu projektu Zbioru praw sadowych Andrzeja Zamoyskiego w 1780 roku sprawa całościowej reformy prawa nie była przedmiotem obrad sejmowych aż do roku $1788^{28}$. Dopiero 28 czerwca 1791 roku sejm powołał jednocześnie dwie komisje (koronną

24 Problematykę prób reformy prawa podejmowanych w Polsce w latach 1764-1788 przedstawił W. Szafrański w przywołanej już monografii opisującej kodeks Stanisława Augusta, poświęcając temu zagadnieniu jeden z jej podrozdziałów (W. Szafrański, op. cit., s. 30-41). Podkreślając imponujący wysiłek inicjatorów idei reform, w tym stanowisko i zasługi w tym względzie samego monarchy, nie pominął on w swej narracji krytycznych uwag dotychczasowych badaczy tej problematyki, formułujących niejednokrotnie bardziej sceptyczne opinie na ten temat (zob. np. J. Michalski, Zagadnienia reformy sadownictwa i prawa sądowego w poczatkach panowania Stanistawa Augusta, „Czasopismo Prawno-Historyczne” 52, 2000, z. 1-2, s. 84; idem, Problematyka reformy sądownictwa i prawa sądowego w okresie sejmu delegacyjnego lat 1767-1768, „Czasopismo Prawno-Historyczne" 54, 2002, z. 2, s. 21-40; G. Bajtruszajtys, Sadownictwo Komisji Skarbowej w sprawach handlowych i przemystowych, Warszawa 1977).

25 „Że zaś w takowym zbiorze nie znayduiemy dogodzenia zamiarom naszym na Seymie 1776 roku wyrażonym, tenże zbior praw wyż wspomniony na zawsze uchylamy”; VL, t. 8, Petersburg 1860 , s. 589.

26 Ibidem.

27 Z. Zielińska, Sejmy polskie z lat 1764-1786, [w:] Parlamentaryzm w Polsce we wspótczesnej historiografii, red. J. Bardach, Warszawa 1995, s. 107.

28 W Szafrański, op. cit., s. 39. 
i litewską) $)^{29}$ do opracowania nowego kodeksu ${ }^{30}$. Nie kwestionując, rzecz jasna, dotychczasowych efektów badań mogących skłonić do podobnej tezy, byłbym jednak ostrożniejszy w formułowaniu opinii na ten temat w podobnie jednoznaczny sposób. Ba, ośmieliłbym się podać ją $\mathrm{w}$ wątpliwość. Wnikliwa analiza poddanych eksploracji diariuszy absolutnie nie skłania do takiego twierdzenia, wprost przeciwnie — zdaje się mu przeczyć. Podkreślam przy tym, iż mam tu na myśli fragmentaryczny obraz rzeczy; taki, jaki wyłania się z ograniczonej, ściśle określonej perspektywy badawczej. W tym kontekście zrozumiałe winno być i to, że pomijam tu intensywność wysiłków podejmowanych przez stosunkowo wąskie grono osób zaangażowanych w prace Komisji w okresie drugiej kadencji Sejmu Wielkiego, takich jak Józef Weyssenhoff ${ }^{31}$, Józef Szymanowski ${ }^{32}$, czy też wizjonerów, do których zaliczany jest Hugo Kołłątaj ${ }^{33}$.

Finis coronat opus Rzeczpospolita Obojga Narodów utraciła swój suwerenny byt w roku 1795. Ostatecznie więc dzieło reformy państwa obiektywnie zakończyło się fiaskiem. Dotyczy to w pełnej rozciągłości oceny efektów reform prawa sądowego podejmowanych w czasach panowania Stanisława Augusta. Pomimo zapowiedzi Ustawy Rządowej z dnia 3 maja 1791 roku prawo przedrozbiorowej Polski pozostało archaiczne i nieskodyfikowane mimo niewątpliwych osiągnięć, jakie w tym zakresie przyniósł okres złotego wieku ${ }^{34}$, co stanowiło wyraźną anomalię

29 W kwestii oceny efektywności prac tej ostatniej, kierowanej przez Józefa Weyssenhofa, wśród historyków panują dość rozbieżne opinie. O ile np. S. Borowski (Kodeks Stanisława Augusta. Zbiór dokumentów, Warszawa 1938, s. V, uw. 2) utrzymuje, że deputacja litewska nie podjęła żadnej działalności, o tyle zgoła odmienne stanowisko reprezentuje Z. Zdrójkowski (Nieznane litewskie prospekty karne J. Weyssenhofa, „Czasopismo Prawno-Historyczne” 10, 1958, z. 1, s. 91-123).

30 I. Jakubowski, op. cit., s. 108.

31 Szerzej na ten temat zob. J. Weyssenhoff, Kronika rodziny Weyssów-Weyssenhoffów, Wilno 1935, passim, wraz z aprobującą recenzją: A. Gieysztor (rec.), J. Weyssenhoff, Kronika rodziny Weyssów-Weyssenhoffów, „Miesięcznik Heraldyczny” 15, 1936, nr 7-8, s. 125-127, a zwł. W. Szafrański, Józef Weyssenhoff — polityk, prawnik, legislator czasów Oświecenia, Poznań 2017, s. 574, wraz z wnikliwą recenzją: S. Salmonowicz (rec.), W. Szafrański, Józef Weyssenhoff — polityk, prawnik, legislator czasów Oświecenia, „Klio. Czasopismo Poświęcone Dziejom Polski i Powszechnym” 2020, nr 1, s. 163-176.

32 Zob. S.K. Potocki, Pochwała J. Szymanowskiego, „Nowy Pamiętnik Warszawski” 2, 1801; F.K. Dmochowski, J. Szymanowski, „Nowy Pamiętnik Warszawski” 1, 1810.

33 Zob. zwł. H. Kołłątaj, Porządek fizyczno-moralny, czyli Nauka o należytościach i powinnościach człowieka wydobytych z praw wiecznych, nieodmiennych i koniecznych przyrodzenia, t. 1, Kraków 1810; E. Giergielewicz, Kotłątaj, Warszawa 1930; idem, Atmosfera ideologiczna Sejmu 4-letniego: (studjum nad publicystyka sejmowa) = L'atmosphère idéologique de la Diète de Quatre Ans: (étude sur les publications relatives à la Diète), Warszawa 1938.

34 Wiek XVI był okresem wzmożonych dążeń kodyfikacyjnych w niemal wszystkich stanowych systemach prawnych: prawa ziemskiego (szlachta), miejskiego czy kościelnego. Kodeksy miały zawierać prawo spisane, usystematyzowane i wolne od wewnętrznych sprzeczności. Akcja kodyfikacyjna zakończyła się tylko częściowym powodzeniem: między innymi w Wielkim Księstwie wprowadzono kolejno trzy statuty litewskie $(1529,1566,1588)$, w ziemskim prawie koronnym częściowo skodyfikowano postępowanie sądowe (Formula processus iudiciarii, 1523), dla 
wobec tendencji rozwojowych europejskiej kultury prawnej w dobie oświecenia ${ }^{35}$. W moim przekonaniu istotnej tego przyczyny upatrywać należy w niedoskonałości kondycji intelektualnej i moralnej zdecydowanej większości reprezentantów narodu politycznego. Ignorancja, brak wykształcenia odpowiadającego dynamicznie zmieniającej się rzeczywistości, wątty potencjał intelektualny, nieświadomość potrzeb i wyznań, wreszcie brak wyobraźni, konsekwencji i deklarowanej odpowiedzialności tak za słowa, jak i czyny (oczywiście nie wszystkich posłów, jednak zdecydowanej ich większości) — w tym upatrywałbym finalnie bodaj najważniejszej przyczyny, która zniweczyła ostatecznie inicjatywy podejmowane przez nielicznych. Pozostałe powody fiaska idei reformy prawa sądowego, których istnienia absolutnie nie neguję, stanowiły ostatecznie jedynie konsekwencje lub okoliczności współistniejące wobec fundamentalnego charakteru praprzyczyny, którą określiłem. W moim przekonaniu dowodzą tego głosy posłów ujawnione w diariuszach sejmowych; wypowiedzi będące odzwierciedleniem ich wiedzy i woli.

\section{Bibliografia}

\section{Źródła archiwalne i zdygitalizowane}

Volumina Legum, t. 8, Petersburg 1860, https://www.wbc.poznan.pl/dlibra/publication/48981/edition/ 65554/content (dostęp: 4.02.2021).

Volumina Legum, t. 9, Kraków 1889, https://www.wbc.poznan.pl/dlibra/publication/49654/edition/ 66193/content (dostęp: 4.02.2021).

Diariusz Sejmu Czteroletniego (sesje 1-71), z drukowanego wydania Jana Pawła Łuszczewskiego, Dyaryusz seymu ordynaryinego pod związkiem Konfederacyi Generalney oboyga narodow w Warszawie rozpoczętego roku 1788, Warszawa Druk. Nadworna J.K.Mci i [...] Kommis. Ed. Narod. 1790, t. 1, cz. 1-2; t. 2, cz. 1-2, https://www.wbc.poznan.pl/dlibra/show-content/ publication/edition/32987?id=32987\&from=FBC (dostęp: 4.02.2021).

Diariusz Sejmu Czteroletniego (sesje 98-198 i 327), z rękopisu przechowywanego w AGAD (w zbiorze Archiwum Sejmu Czteroletniego, rozproszony w różnych tomach) autorstwa Jana Pawła Łuszczewskiego, Antoniego Siarczyńskiego i in., https://www.wbc.poznan.pl/dlibra/ publication/20159/edition/32995/content (dostęp: 4.02.2021).

szlachty z Prus Królewskich wprowadzono korekturę pruską (1598). Nie powiodła się natomiast kodyfikacja całości prawa koronnego, powstały w 1532 roku projekt Correctura iurium został odrzucony, efektów nie przyniosły też prace prowadzone na przełomie XVI i XVII wieku. W prawie miejskim sankcję królewską otrzymał dokonany w 1535 roku przez Marcina Jaskiera przekład na język łaciński Weichbildu magdeburskiego i Zwierciadła saskiego, nie uzyskały jej jednak późniejsze: projekt kodyfikacji prawa miejskiego autorstwa Macieja Śliwnickiego oraz rewizje prawa chełmińskiego. W tym ostatnim przypadku przyjmowały je jednak poszczególne miasta. W praktyce sądowej posiłkowano się również pracami prawniczymi Bartłomieja Groickiego, Pawła Szczerbica czy Andrzeja Lipskiego; por. A. Moniuszko, Prawo sadowe Rzeczypospolitej szlacheckiej (XVIXVIII w.). Zarys wykładu z wyborem źródet, Warszawa 2017, s. 12.

35 XVIII stulecie nieprzypadkowo zwane jest w dziejach Europy wiekiem kodyfikacji; pierwsze kodeksy powstały w Bawarii już w latach pięćdziesiątych XVIII wieku. 


\section{Literatura}

Bajtruszajtys G., Sadownictwo Komisji Skarbowej w sprawach handlowych i przemystowych, Warszawa 1977.

Boniecki A., Reiski A., Herbarz polski, t. 16, Warszawa 1913.

Borkowska-Bagieńska E., Zbiór praw sqadowych Andrzeja Zamoyskiego, Poznań 1986.

Borowski S., Kodeks Stanisława Augusta. Zbiór dokumentów, Warszawa 1938.

Chojecki R., Stanisław August a proces Adama Ponińskiego, „Przegląd Historyczny” 63, 1972, nr 1.

Chyra-Rolicz Z., Gabinet Stanisława Augusta, [w:] Dzieje biurokracji na ziemiach polskich, t. 1, red. A. Górak, I. Łuć, D. Magier, Lublin-Siedlce 2008.

Dmochowski F.K., J. Szymanowski, „Nowy Pamiętnik Warszawski” 1, 1810.

Giergielewicz E., Atmosfera ideologiczna Sejmu 4-letniego: (studjum nad publicystyka sejmowa) = L'atmosphère idéologique de la Diète de Quatre Ans: (étude sur les publications relatives à la Diète), Warszawa 1938.

Giergielewicz E., Kołtątaj, Warszawa 1930.

Gieysztor A. (rec.), J. Weyssenhoff, Kronika rodziny Weyssów-Weyssenhoffów, „Miesięcznik Heraldyczny" 15, 1936, nr 7-8.

Grześkowiak-Krwawicz A., Siarczyński Antoni (1757-1842), [w:] Polski Stownik Biograficzny, t. 36. Schroeder Franciszek - Siemiatycki Chaim, Warszawa-Kraków 1995-1996.

Jakubowski I., Kodyfikacje prawa polskiego w wieku oświecenia i spór o role prawa rzymskiego na poczatku XIX stulecia, „Studia Prawno-Ekonomiczne” 80, 2009.

Kołłątaj H., Porządek fizyczno-moralny, czyli Nauka o należytościach i powinnościach człowieka wydobytych z praw wiecznych, nieodmiennych i koniecznych przyrodzenia, t. 1, Kraków 1810.

Kurdybacha Ł., Dzieje kodeksu Andrzeja Zamoyskiego, Warszawa 1951.

Michalski J., Problematyka reformy sądownictwa i prawa sadowego w okresie sejmu delegacyjnego lat 1767-1768, „Czasopismo Prawno-Historyczne” 54, 2002, z. 2.

Michalski J., Zagadnienia reformy sadownictwa i prawa sadowego w poczatkach panowania Stanistawa Augusta, „Czasopismo Prawno-Historyczne” 52, 2000, z. 1-2.

Moniuszko A., Prawo sądowe Rzeczypospolitej szlacheckiej (XVI-XVIII w.). Zarys wykładu z wyborem źródet, Warszawa 2017.

Nowicki J., Diariusze sejmowe z XVIII wieku, „Mówią Wieki” 10, 1998.

Pieńkowski M. (rec.), Diariusze sejmu koronacyjnego Zygmunta III Wazy 1587/1588 roku, Kraków 2016, „Klio. Czasopismo Poświęcone Dziejom Polski i Powszechnym” 40, 2017, nr 1.

Potocki S.K., Pochwała J. Szymanowskiego, „Nowy Pamiętnik Warszawski” 2, 1801.

Rymszyna M., Gabinet Stanisława Augusta Poniatowskiego, Warszawa 1962.

Salmonowicz S. (rec.), W. Szafrański, Józef Weyssenhoff - polityk, prawnik, legislator czasów Oświecenia, „Klio. Czasopismo Poświęcone Dziejom Polski i Powszechnym” 52, 2020, nr 1.

Serczyk W.A., Hajdamacy, Kraków 1978.

Siarczyński A., Dzień Trzeci Maia roku 1791, Księga JKM, Warszawa 1791.

Smoleński W., Przyczyny upadku projektu kodeksu Zamoyskiego, [w:] Pisma historyczne, t. 1, Kraków 1901.

Srogosz T., Zagrożenie bezpieczeństwa na kresach poludniowo wschodnich Rzeczypospolitej w końcu lat osiemdziesiatych XVIII wieku w świetle korespondencji wojewody kijowskiego Józefa Gabriela Stempkowskiego, „Prace Naukowe Akademii im. Jana Długosza w Częstochowie. Zeszyty Historyczne" 13, 2014.

Szafrański W., Józef Weyssenhoff — polityk, prawnik, legislator czasów Oświecenia, Poznań 2017.

Szafrański W., Kodeks Stanisława Augusta, Poznań 2007.

Szczygielski W., Z badań nad początkami obrad Sejmu Wielkiego, „Przegląd Nauk Historycznych” 7,2008, nr 1 .

Tarnowski M., Kodeks Zamoyskiego na tle stosunków kościelno-państwowych za czasów Stanisława Augusta, Lwów 1916. 
Trąbski M., Zagrożenie buntem chłopskim w poludniowo wschodnich województwach Rzeczypospolitej Obojga Narodów w latach 1788-1789, „Orientalia Christiana Cracoviensia” 2015, nr 7.

Uruski S., Rodzina. Herbarz szlachty polskiej, t. 10, Warszawa 1913.

Weyssenhoff J., Kronika rodziny Weyssów-Weyssenhoffów, Wilno 1935.

Wiązek P., O powołaniu naszych czasów do ustawodawstwa: konsolidacja, unifikacja, korektura czy kodyfikacja? Polemiki wokół ponderabiliów w sporze o reforme prawa sadowego u schyłku osiemnastowiecznej Rzeczpospolitej, „Prawo” 314, 2012.

Wiązek P., Wyderkauf jako forma obejścia przepisów o lichwie w prawie przedrozbiorowej Polski, [w:] Regulacje prawne gospodarki w rozwoju historycznym, red. A. Szymańska, Wrocław 2017.

Zdrójkowski Z., Nieznane litewskie prospekty karne J. Weyssenhofa, „Czasopismo Prawno-Historyczne" 10, 1958, z. 1.

Zielińska Z., Sejmy polskie z lat 1764-1786, [w:] Parlamentaryzm w Polsce we wspótczesnej historiografii, red. J. Bardach, Warszawa 1995.

\section{Źródła internetowe}

Kalinowska A., Diariusze sejmowe, „Silva Rerum”, https://www.wilanow-palac.pl/diariusze_sejmowe.html (dostęp: 4.02.2021).

Michałowska-Walkiewicz E., Jan Pawet Łuszczewski - polski polityk Księstwa Warszawskiego, https://poland.us/strona,13,30673,0,jan-pawel-luszczewski-polski-polityk-ksiestwa-warszawskiego.html (dostęp: 4.02.2021).

\section{Deputies against the problem of judicial law reform in the first year of the session of the Grand Sejm, in the light of the parliamentary diaries by Jan Paweł Łuszczewski and Antoni Siarczyński}

\section{Summary}

In 1788, in the face of the deepening crisis of the state and the real threat of losing sovereign existence, an extraordinary Sejm was convened in the Polish-Lithuanian Commonwealth, whose decisions and reforms were to save the independence of the state, while at the same time thoroughly modernising it. This congregation went down in history as the Four-Year or Grand Sejm, which many saw and still see as an appreciation of its great work. One of the actions taken was a profound reform of judicial law, the anachronistic nature of which was a significant cause of the country's weakness and the problems of its citizens. Ultimately, however, somewhat paradoxically, the glorious and greatest achievement of the assembly — adopting a constitution — resulted in a civil war, a military conflict with a powerful neighbor - Tsarist Russia, and the liquidation of the Polish state.

The aforementioned basic law devoted one of its articles to the judiciary, obliging it to create a new legal code. However, this commitment was never fulfilled. The question of why this happened is still open. The attempt to answer this question is part of the fundamental dispute over the causes of the collapse and liquidation of the state, a discourse that has provoked passionate polemics for decades.

The author made an attempt to take his own position on this issue, based on the results of the undertaken research. He conducted a thorough analysis of exceptionally valuable sources such as 
the Sejm diaries, which constitute a record of the deputies' speeches at the forum of the plenary Sejm sessions, similar to modern meeting records. In the actions and attitudes of the nation's representatives, at the moment of his greatest attempt, he tried to find the key to resolving the dispute.

Keywords: history of law, judicial law, law reform, parliamentarism, legislation.

\section{Die Abgeordneten angesichts der Frage der Reform des Gerichtsrechts im ersten Tagungsjahr des Großen Sejm anhand der Sejm-Protokollbücher von Jan Paweł Łuszczewski und Antoni Siarczyński}

\section{Zusammenfassung}

In Anbetracht der sich vertiefenden Krise des Staates und der realen Gefahr, die Souveränität zu verlieren, wurde im Jahr 1788 in der Republik beider Nationen der außerordentliche Sejm einberufen, dessen Entscheidungen und Reformen die Unabhängigkeit des Staates retten und ihn dabei tief modernisieren sollten. Diese Versammlung schrieb Geschichte als der Vierjährige oder Große Sejm, worin viele die Anerkennung der Größe seiner Werke sahen und sehen. Eine der eingeschlagenen Richtungen seiner Tätigkeit war die Reform des Gerichtsrechts, dessen veralteter Charakter einen wichtigen Grund für die Schwächen des Staates und die Probleme seiner Bürger darstellte. Letztendlich jedoch, ein wenig paradox, führte der lobenswerte und wichtigste Erfolg der Versammlung — die Verabschiedung der Verfassung — zum Ausbruch des Hauskrieges, zum militärischen Konflikt mit dem großen Nachbar — Zarenrussland und zur Auflösung des Staates.

Ein der Artikel dieses Grundgesetzes wurde der rechtsprechenden Gewalt gewidmet und verpflichtete dazu, ein neues Gesetzbuch zu verfassen. Dieser Verpflichtung ist jedoch nie nachgekommen worden. Offen bleibt immer noch die Frage — warum. Der Versuch, sie zu beantworten stellt einen Bestandteil des fundamentalen Streites um die Gründe des Zusammenbruchs und der Auflösung des Staates dar, einer Diskussion, die bereits über Jahrzehnte zur bewegten Polemik führt.

Der Autor versuchte, anhand der geführten Forschungen, eigene Stellung dazu zu nehmen. Eingehende und gründliche Analyse der besonders wertvollen Quellen — der Sejm-Protokollbücher, der Niederschrift der Abgeordnetenauftritte während der Plenarsitzungen des Sejm, die den gegenwärtigen Stenogrammen ähneln, machte er zum Wesen dieser Forschungen. Im Tun und Haltung der Vertreter des Volkes zum Zeitpunkt der größten Probe versuchte er, den Schlüssel zur Entscheidung des Streites zu finden.

Schlüsselwörter: Rechtsgeschichte, Gerichtsrecht, Reform des Rechts, Parlamentarismus, Gesetzgebung. 